Original paper

\title{
Delineating the Coral Triangle
}

\section{J.E.N. VERON ${ }^{1,2, *}$, Lyndon M. DEVANTIER ${ }^{1,2}$, Emre TURAK ${ }^{1,2}$, Alison L. GREEN ${ }^{3}$, Stuart KININMONTH ${ }^{2}$, Mary STAFFORD-SMITH ${ }^{1}$, and Nate PETERSON ${ }^{3}$}

\author{
${ }^{1}$ Coral Reef Research, 10 Benalla Road, Oak Valley, Townsville 4811, Australia \\ ${ }^{2}$ Australian Institute of Marine Science, MSO Townsville 4811, Australia \\ ${ }^{3}$ The Nature Conservancy, 51 Edmondstone Street, South Brisbane 4101, Australia \\ * Corresponding author: J.E.N. Veron \\ E-mail: j.veron@coralreefresearch.com
}

Communicated by Makoto Tsuchiya

\begin{abstract}
Spatial analyses of coral distributions at species level delineate the Coral Triangle and provide new insights into patterns of diversity and endemism around the globe. This study shows that the Coral Triangle, an area extending from the Philippines to the Solomon Islands, has 605 zooxanthellate corals including 15 regional endemics. This amounts to $76 \%$ of the world's total species complement, giving this province the world's highest conservation priority. Within the Coral Triangle, highest richness resides in the Bird's Head Peninsula of Indonesian Papua which hosts 574 species, with individual reefs supporting up to 280 species $\mathrm{ha}^{-1}$. Reasons for the exceptional richness of the Coral Triangle include the geological setting, physical environment and an array of ecological processes. These findings, supported by parallel distributions of reef fishes and other taxa, provide a clear scientific justification for the Coral Triangle Initiative, arguably one of the world's most significant reef conservation undertakings.
\end{abstract}

Keywords coral biodiversity, reef conservation, coral triangle initiative, coral biogeography

\section{Introduction}

"If we look at a globe or a map of the Eastern Hemisphere, we shall perceive between Asia and Australia a number of large and small islands, forming a connected group distinct from those great masses of land and having little connexion with either of them. Situated upon the equator, and bathed in the tepid water of the great tropical oceans, this region enjoys a climate more uniformly hot and moist than almost any other part of the globe, and teems with natural productions which are elsewhere unknown." So begins Alfred Russel Wallace's seminal book The Malay Archipelago, first published in 1869 (Wallace, 1869) and destined to become one of the foundations of modern biogeography.

Wallace, concurrently with Darwin, looked for an interpretation of modern faunal distributions in the light of past evolutionary events. In 1863 he read a paper to the Royal Geographical Society (Wallace, 1863) which had a red line on a map starting at the deep strait between Bali and Lombok and passing down the Makassar Strait. To the west he wrote 'Indo-Malayan region' and to the east, 'Austro-Malayan region'. This line, dubbed 'Wallace's line' by T.H. Huxley in 1868 has since become one of the best-known demarcations in the history of biogeography, 
yet it is one that was constantly questioned. Huxley redrew it to run west of the Philippines, Wallace himself changed his mind (Wallace, 1910), and different lines were drawn by other authors as a result of studies of different animal distributions (Fig. 1).

The marine realm was virtually ignored by these as well as other authors of the time although there were occasional attempts to map marine life, notably by the American geologist James Dana (1853), the British naturalist Edward Forbes (1856) as well as Charles Darwin himself (1859). There were a few scattered publications on the distribution of some marine taxa during the latter part of the $19^{\text {th }}$ century (George 1981), but it was not until the publication of Bartholomew's Atlas in 1911 and Ekman's historic compendium in 1935 that marine biogeography became established as a science in its own right.

Over the past several decades, biogeographers have proposed centres of marine biodiversity of varying shapes, all centred on the Indonesian/Philippines Archipelago. Some stem from biogeographic theory or geological history, others from coral and reef fish distributions. These centres have been given a variety of names: Wallacea, East Indies Triangle, Indo-Malayan Triangle, Western Pacific Diversity Triangle, Indo-Australian Archipelago, Southeast Asian centre of diversity, Central Indo-Pacific biodiversity hotspot, Marine East Indies, among others
(Hoeksema 2007).

It was not until the post-war era that coral biogeography came to the forefront of marine biogeography, a position launched by the American palaeontologist John Wells (1954) when he published a table of coral genera plotted against locations. Many re-iterations of this table formed the basis of sequence of published maps (Stehli and Wells 1971; Rosen 1971; Coudray and Montaggioni 1982; Veron 1993). These publications, all at generic level, highlighted the Indonesian/Philippines Archipelago as the centre of coral diversity. Significantly, they also included the Great Barrier Reef of Australian as part of that centre.

This view was fundamentally altered when global distributions were first compiled at species level, an undertaking which needed a computer-based spatial database. This compilation clearly indicated that the IndonesianPhilippines archipelago, but not the Great Barrier Reef, was the real centre of coral diversity (Veron 1995), a pattern now well-established (see below).

The significance of this seemingly innocuous finding was not lost on conservationists. It meant that the international focus for coral and (by extrapolation) reef conservation shifted from the highly regulated World Heritage province of the Great Barrier Reef to the relatively under-studied region to the north, where reefs were largely unprotected, and where human population densities and consequent environmental impacts were high by most

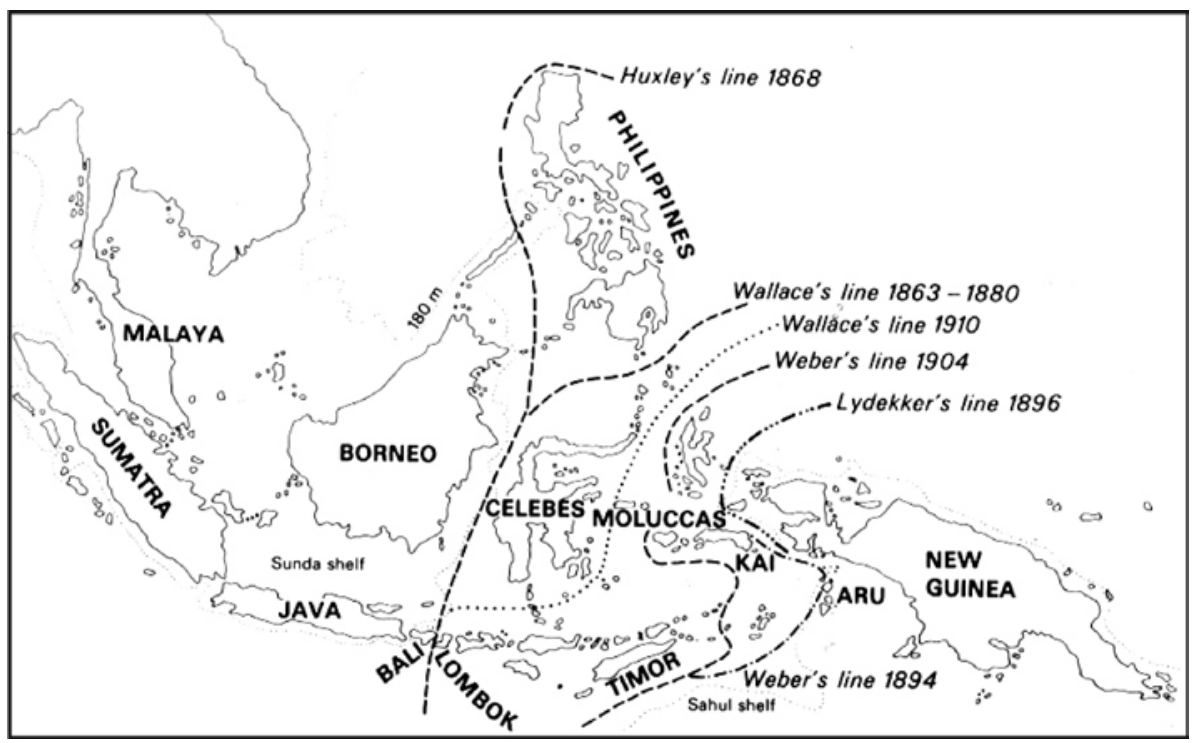

Fig. 1 Historical demarcations between the Oriental and Australian faunal regions (after George 1964) 
world standards.

Political response to the delineation of the Coral Triangle (CT) was prompt. In September, 2007, twenty-one world leaders attending the Asia Pacific Economic Cooperation (APEC) summit in Sydney proposed the Coral Triangle Initiative (CTI) as a mechanism to conserve key components of the global centre of coral reef biodiversity. The Government of Indonesia promptly followed in December with a formal establishment of the CTI following a two-day symposium on the subject in parallel with the Bali UN Framework Convention on Climate Change. Since then, the CTI has been one of the biggest conservation initiatives ever undertaken in the marine world.

\section{Methods}

The scientific basis for the abovementioned events was established by the spatial database Coral Geographic, a major update of the original species maps of Veron (2000). This database contains comprehensive global species maps of zooxanthellate coral distributions in GIS format, allowing them to be interrogated to compare geographic regions or to elucidate patterns of diversity and endemism.

The 798 species maps in the Coral Geographic database are each divided into 141 ecoregions (Fig. 2, below), an approach increasingly used in biogeography (Spalding et al. 2007). These maps, which include verified published occurrences of each species in each ecoregion together with original data are from two sources: (1) revisions of the database used to generate the species distribution maps of Veron (2000) and (2) species complements derived from original fieldwork by the first three authors in 83 of the 141 ecoregions. Continually updated details of this dataset, currently including $>2500$ geo-referenced sites linked to habitat data, will be available on-line in 2010 .

Because of their wide intraspecific variability, corals are difficult to identify, both in the field and laboratory. In compiling the database of Coral Geographic, field identifications were used where they were considered reliable and voucher specimens were retained where appropriate for taxonomic work, a process that underpins most biogeography. Depending on requirements of host countries, voucher specimens were either deposited in museums appropriate for the location of the fieldwork, or the Museum of Tropical Queensland, Australia. Taxonomic and field-recognition characters of species are detailed in Veron \& Stafford-Smith (2002). These species distribution maps will change with future fieldwork: currently known ranges will be extended and distributions will become ever-more detailed. This report, therefore, has boundary conditions: (1) Unless otherwise indicated, species occurrences are believed to be comprehensive at the level of ecoregions, but not necessarily to subdivisions of ecoregions. (2) Species included are those recognised by Veron (2000), a compilation which has little or no geographic bias. There are at least 45 additional known species not included in this analysis because most are undescribed and all have unknown distribution ranges. However, these re-enforce the CT boundary, they do not change its position. (3) Both field and taxonomic effort is greatest within the CT, Japan, Australia, Madagascar, the Red Sea, coastal east Africa, coastal mainland Asia and Atlantic localities, whilst some other regions, notably island nations with large oceanic territories, are less wellknown.

\section{Results}

Locations of ecoregions and the number of species found in each are indicated in Fig. 2. Figure 3 shows the general pattern of global distribution of zooxanthellate corals generated by Coral Geographic (see text). This compilation places the CT in global context. Sixteen ecoregions of the world have $>500$ species; these define the CT and reveal its internal components to the level or resolution of this study (Fig. 4).

\section{Characteristics of the Coral Triangle}

In total, the CT has 605 zooxanthellate coral species of which $66 \%$ are common to all ecoregions. This diversity amounts to $76 \%$ of the world's total species complement. Within the CT, highest richness resides in the Bird's Head 


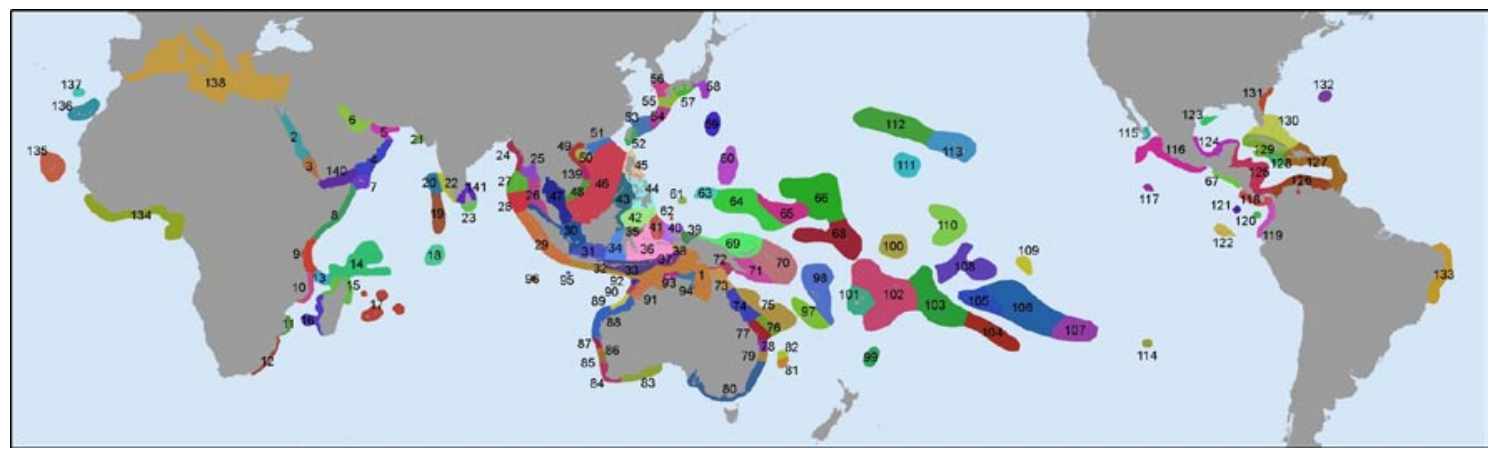

Fig. 2 Ecoregions of the world, delineated on the basis of known internal faunal and/or environmental uniformity and external distinctiveness from neighbouring regions. The number of species recorded in each ecoregion (in bold) is: (1) Arafura Sea 127; (2) North \& central Red Sea 289; (3) South Red Sea 297; (4) South-east Arabian coast (Arabian Sea) 204; (5) Gulf of Oman 56; (6) Persian Gulf 51; (7) Socotra Archipelago 251; (8) East Somali coast 182; (9) Kenya \& Tanzania coast 300; (10) North Mozambique coast 296; (11) South Mozambique coast 226; (12) Eastern South Africa coast 36; (13) Mayote \& the Comoro Islands 293; (14) Aldabra \& the Seychelles 305; (15) North Madagascar 353; (16) West Madagascar 318; (17) Mascarene Islands 244; (18) Chagos Archipelago 275; (19) Maldive Islands 237; (20) Lakshadweep 140; (21) Gulf of Kuch 72; (22) Southwest India Coast 228; (23) South Sri Lanka 289; (24) North Burmese coast 27; (25) Gulf of Martaban (Burma) 51; (26) Andaman Sea 339; (27) Andaman Islands 242; (28) Nicobar Islands 305; (29) West Sumatra 386; (30) Strait of Malacca \& Selat Karimata 407; (31) Java Sea 454; (32) Java 462; (33) Lesser Sunda Islands and the Savu Sea 523; (34) Makassar Strait 511; (35) Gulf of Tomini 518; (36) Banda Sea and the Muluccas 533; (37) North Arafura Sea islands 503; (38) SW coast of Papua 540; (39) Cendrawasih Bay 515; (40) Raja Ampat, Bird's Head Peninsula 553; (41) Halmahera 544; (42) Celebes Sea 545; (43) Sulu Sea 540; (44) Southeast Philippines 533; (45) North Philippines 510; (46) South China Sea 435; (47) Gulf of Thailand 404; (48) South Vietnam 397; (49) North Vietnam 182; (50) Hainan 275; (51) Hong Kong 94; (52) Taiwan 373; (53) Southern Ryukyu Is 399; (54) North Ryukyu Islands 366; (55) Southeast Kyushu 233; (56) North Kyushu \& South Korea 166; (57) Shikoku 162; (58) Honshu 89; (59) Ogasawara Gunto \& Kazan Retto 84; (60) Guam \& the Marianas 189; (61) Palau 306; (62) Southwest Islands \& Helen Reef 376; (63) Yap Islands 292; (64) Caroline Islands (Central FSM) 359; (65) Pohnpei and Kosrae (East FSM) 395; (66) Marshall Islands 325; (67) Guatemala, El Salvador, Nicaragua Pacific Coast 25; (68) Gilbert Islands (Kiribati West) 330; (69) Bismarck Sea 514; (70) Solomon Islands \& Bougainville 507; (71) Milne Bay 511; (72) Gulf of Papua 379; (73) Torres Strait \& far Northern GBR 410; (74) Central \& North GBR 402; (75) Coral Sea 354; (76) Pompey \& Swain Reefs, South-east GBR 370; (77) Central GBR islands and Southern GBR 366; (78) Moreton Bay 160; (79) Solitary Islands 114; (80) South-east Australia 22; (81) Lord Howe Island 76; (82) Elizabeth \& Middleton Reefs 153; (83) Recherche Archipelago 9; (84) SW West Australia 40; (85) Direction Bank 180; (86) Houtman Abrolhos Islands (Australia) 281; (87) Shark Bay 283; (88) Ningaloo Reef \& NW Western Australia 311; (89) Rowley Shoals 270; (90) Scott Reef 300; (91) Kimberley Coast 314; (92) Ashmore Reef 405; (93) Darwin 267; (94) Arnhem Land 233; (95) Christmas Island 100; (96) Cocos Keeling (Indian Ocean) 107; (97) New Caledonia 350; (98) Vanuatu 384; (99) Kermedec Islands 9; (100) Phoenix Islands (Kiribati Centre) 189; (101) Fiji 366; (102) Tuvalu, Samoa, Tonga 329; (103) Cook Islands 186; (104) Austral Islands 161; (105) Society Islands 175; (106) Tuamotu Archipelago West 173; (107) Pitcairn - Tuamoto SE 64; (108) Line Islands - South (SE Kiribati) 156; (109) Marquesas Islands 26; (110) Line Islands - North (NE Kiribati) 83; (111) Johnston Atoll 65; (112) North-west Hawaii 47; (113) Hawaii East (Greater Islands) 62; (114) Easter island 40; (115) Baja California - South 22; (116) Mexico Pacific Coast \& Revillagigedo Islands 34; (117) Clipperton Atoll 10; (118) Costa Rica, Panama Pacific coast 28; (119) Colombia, Ecuador Pacific Coast 27; (120) Isla de Malpelo 23; (121) Isla del Coco 25; (122) Galapagos Islands 26; (123) Flower Garden Banks 31; (124) Bay of Campeche, Yucatan 55; (125) Belize \& West Caribbean 55; (126)_South Caribbean \& Netherlands Antilles 55; (127) Hispaniola, Puerto Rico and Lesser Antilles 55; (128) Jamaica 55; (129) Cuba \& Cayman Islands 55; (130) Bahamas \& Florida South 58; (131) Florida North to South Carolina 34; (132) Bermuda 25; (133) Brazil 17; (134) Gulf of Guinea to Sierra Leone 9; (135) Cape Verde 9; (136) Canary Islands 2; (137) Madeira Islands 6; (138) Mediterranean 4; (139) Central Vietnam 334; (140) Gulf of Aden 223; (141) Gulf of Mannar \& NE Sri Lanka 244 


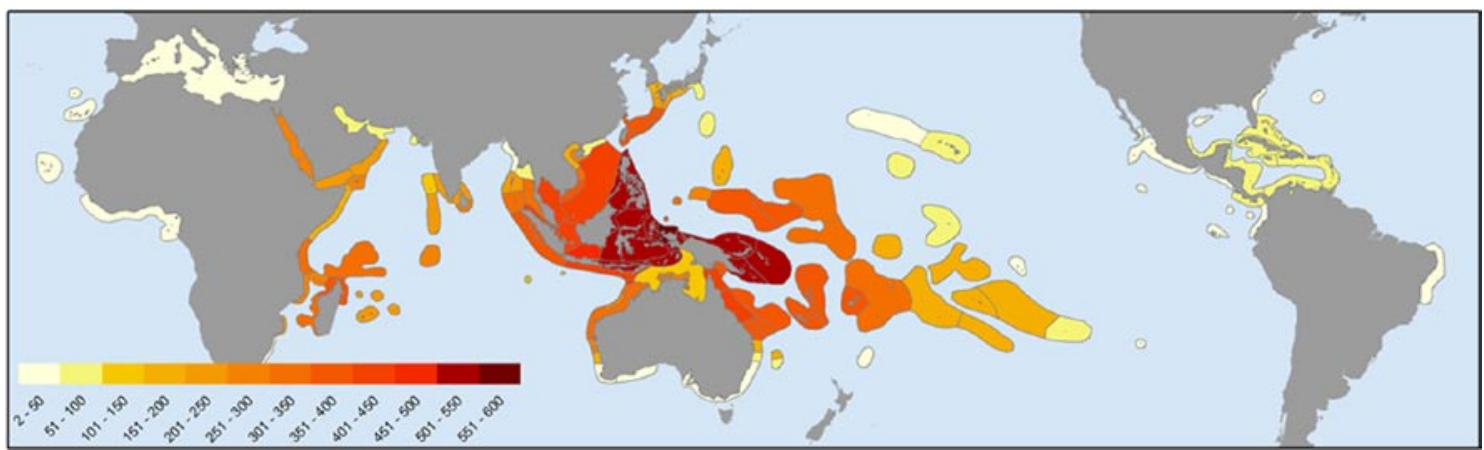

Fig. 3 Global biodiversity of zooxanthellate corals. Colours indicate total species richness of the world's 141 coral biogeographic 'ecoregions' (From the spatial database Coral Geographic, see text)
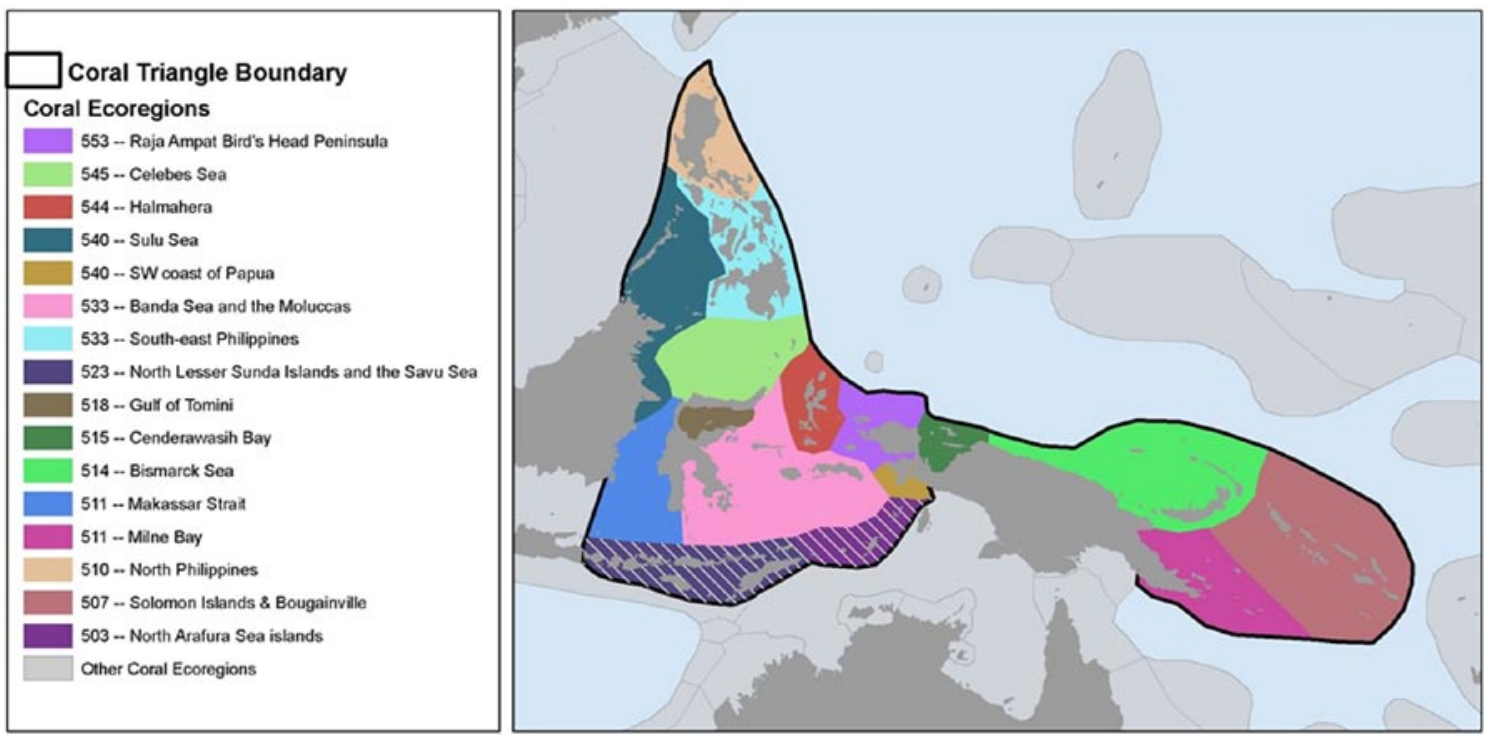

Fig. 4 Ecoregions and species richness of zooxanthellate corals of the CT (determined by the spatial database Coral Geographic, see text). A total of 1118 sites were studied within the 16 ecoregions of this province (left panel, showing number of species per ecoregion), however some islands of southern Indonesia (the two hatched ecoregions), especially their southern coastlines, remain data-deficient. Each ecoregion has $>500$ species

Peninsula of Indonesian Papua, which hosts 574 species. Individual reefs there have up to 280 species $\mathrm{ha}^{-1}$, over four times the total zooxanthellate scleractinian species richness of the entire Atlantic Ocean (Turak and DeVantier in press). Within the Bird's Head, The Raja Ampat Islands ecoregion has the world's coral highest biodiversity, with 553 species (Turak and Souhoka 2003).

Importantly, boundaries of the Raja Ampat islands and the Birds Head diversity centre are not strongly delineated. More than $80 \%$ of all $\mathrm{CT}$ species are found in at least 12 of the $16 \mathrm{CT}$ ecoregions. Nor is this region markedly distinct from neighbouring ecoregions. Ninety-five per cent of $\mathrm{CT}$ species are found in one or more adjacent ecoregions (notably other parts of SE Asia (including Malaysia, Thailand and Vietnam) Japan, Micronesia, the Great Barrier Reef, Vanuatu, New Caledonia and Fiji although all exhibit marked attenuation in species richness and ubiquitousness.

The CT area contains 52\% of Indo-Pacific reef fishes (37\% of reef fishes of the world) (Allen 2007). Other major faunal groups, notably molluscs (Wells 2002) and crustaceans (Grave 2001), have very high numbers of 
undescribed or cryptic species and thus are relatively little-known at species level (Meyer et al. 2005). However, many biogeographic publications indicate that a wide variety of taxa not necessarily associated with reefs reach maximum diversity in areas within the CT (Briggs 2005). Although most of these taxa occupy shallow marine habitats, coral reefs are sometimes of secondary importance as habitats, as seen in the distributions of mangroves (Ricklefs and Latham 1993; Hogarth 1999; Groombridge and Jenkins 2002) and seagrass (Spalding et al. 2003) which also have highest diversity within the CT. Even azooxanthellate corals, which have none of the physiological restrictions of zooxanthellate species, have a centre of global diversity within the CT (Cairns 2007). These diversity maxima of fauna and flora, especially those not associated with reefs, are only seen in areas large enough to contain an extreme diversity of habitats created by the complex coastlines of island archipelagos.

\section{The role of the Coral Triangle in conserva- tion}

There is currently high level political support for establishing globally representative Marine Protected Area (MPA) networks through multilateral agreements and programs (reviewed, Bryant et al. 1998; Kelleher 1999). The 2001 World Summit on Sustainable Development, the 2003 World Parks Congress, and the 2003 Convention of Biological Diversity, all called on governments, nongovernment organisations and communities to establish, by 2012 , a global system of effectively managed representative networks of MPAs to support sustainable fisheries and biodiversity conservation.

In order to establish a globally representative network of MPAs and to help prioritization, it is essential to understand how biodiversity is distributed, especially to avoid a mismatch between patterns in biodiversity and conservation spending (Halpern et al. 2006). Recently, Spalding et al. (2007) provided an analysis of marine ecoregions of the world. These authors focus on coastal and shelf waters, combining benthic and shelf pelagic (neritic) biotas.

Apart from its role in establishing the CT, Coral Geo- graphic has contributed to most reef conservation initiatives in the Indo-Pacific over the past 20 years. One recent outcome, co-authored by the first three authors of this study, is that of Carpenter et al. (2008) who concluded that $32.8 \%$ of zooxanthellate corals are threatened.

\section{Reasons for existence of the Coral Triangle}

So much interest from so many points of view begs the question: why does the CT exist? There is no one simple answer, rather there are several interacting factors operating over different temporal and spatial scales.

Geological history. Two aspects of the geological history of the $\mathrm{CT}$ are relevant:

(1) The southern half of the CT has been tectonically unstable as far back as the Eocene (38 million years ago), creating a constantly changing geography leading to repeated environmental perturbations, habitat complexity and (it can only be presumed) evolutionary changes. The Philippines archipelago has had different, perhaps a less dramatic geological past although the Miocene Ryukyu limestones, extending from Japan to Indonesia, show that reef distributions have changed beyond recognition over that time. The fossil record suggests that the corals of the $\mathrm{CT}$ are the world's youngest - less than half the mean age of their Caribbean counterparts. These relatively young genera either evolved in the region of the $\mathrm{CT}$ or have survived there since going extinct elsewhere (Stehli and Wells 1971; Veron 1995).

(2) However important plate tectonic movements were to ocean circulation patterns of the distant past, they are small when compared with the impacts of sea-level changes during the Pleistocene. At least eight times during the last two million years the shorelines of the CT region have alternated between present sea level and minus 130 m (approximately) (Siddall et al. (2003). All reefs were repeatedly aerially exposed, yet deep water remained in close proximity. The $\mathrm{CT}$ is thus characterised by complex island shorelines creating diverse shallow habitats adjacent to deep $(>150 \mathrm{~m})$ ocean. This created conditions for minimal broad-scale dislocation during times of rapid sea-level change, while also causing more localized changes in oceanographic patterns and isolation of popu- 
lations to greater or lesser degree within marginal seas and large embayments, thus driving reticulation (see below).

Dispersion also has answers:

(1) The CT acts as a 'catch-all' for larvae moving towards the region, entrained in both the South Equatorial Current and the North Equatorial Current (Jokiel and Martinelli 1992; Veron 1995).

(2) Dispersion occurs away from the CT so that, at progressively increasing distance, species attenuate according to ocean temperature (a) northward to mainland Japan, dispersed by the Kuroshio, (b) southward along the west Australian coast, dispersed by the Indonesian Through-flow and the Leeuwin Current and (c) southward along the east Australian coast, dispersed by the East Australian Current (Wells 1955; Veron 1995). This suggests that the CT is the most diverse part of the whole central Indo-Pacific simply because all other regions have attenuated species richness.

(3) Complex eddies created by the Indonesian Throughflow (Gordon and Fine 1996) drive genetic mixing which constantly changes with wind, season and (over geological time) sea level. Genetic mixing of this nature creates genetic heterogeneity through vicariance (see below); it also drives reticulate evolution (see below).

Biogeographic patterns. Biodiversity is reflected in biogeographic patterns and the environments that created those patterns:

(1) Diversity may be the result of (a) a high level of endemism or (b) the overlap in the ranges of species with wide ranges. Importantly, the first category contributes only $2.5 \%$ of the coral diversity of the CT. The biodiversity of corals is therefore due to the overlap of species ranges, ranges which extend eastwards into the Pacific and westwards into the Indian Ocean. Endemism becomes relatively more important with fish (Allen, 2006) and other taxa in which species longevity is less than that of corals or which have a lesser capacity for long distance dispersal or which are specialised for narrow niches.

(2) Ocean temperatures of the $\mathrm{CT}$ are commonly near the thermal cap of $31^{\circ} \mathrm{C}$ (Kleypas et al. 2008). This temperature, or maxima close to it, is commonly maintained for months during the summer of much of the CT. It is a well-established maxim of biogeography ('Rapoport's
Rule') that the mean latitudinal range of major taxa increases with increasing latitude (Stevens 1989). This is another way of saying that increasing latitude is correlated with increasing environmental tolerance. Perhaps this is less well established for marine life (Clarke 1992), but it does suggest that temperature tolerance is least limiting at equatorial latitudes.

Evolution Because it links many scientific disciplines including taxonomy, biogeography and genetics, the subject of evolution has led to several general theories, three of which (Darwin's Centres of Origin, Vicariance and Reticulate Evolution) have special relevance to marine biodiversity, biogeography and (therefore) the CT.

(1) Darwin's Centres of Origin: Darwin (1859) proposed that dispersion was primarily driven by the evolution of new species through natural selection, a process where older and less competitive species become displaced from their place of origin to more distant places by fitter and more competitive descendant species. Darwin's Centres of Origin theory, or refinements of it, dominated all marine biogeographical thinking until the theory of continental drift appeared to make a fundamental aspect of it - geographic centres - untenable (Briggs 1984). Interest in this theory, at least as far as corals are concerned, is historical for there are no identifiable centres of origin, only centres of diversity created by overlapping species ranges.

(2) Vicariance: Once heralded as the theory that puts and end to Darwinism (McCoy and Heck 1976), vicariance evolutionary theory proposes that, if one or more barriers forms across a species' distribution, the divided population might diverge in time forming two or more distinct populations. If these remain reproductively isolated after the barriers are removed, they may continue to exist as two or more independent species. This process on a larger scale leads to patterns of species that have no centre of origin. There is no requirement for dispersion to occur. Vicariance may indeed have relevance to many genetic processes, however it is a concept that leads to unending exponential increase in species numbers and lacks relevance to most marine taxa that have great powers of long distance dispersal. Furthermore it necessitates that species be considered as units rather than artificiallydefined pieces of genetic continua. Vicariance is the 
forerunner of the theory of reticulate evolution.

(3) Reticulate Evolution: This is arguably the main mechanism of evolutionary change in most marine taxa. It recognises (a) that currents are both genetic barriers (as in vicariance) and paths of genetic connectivity, (b) that 'species' fuse as well as divide in time and space, (c) that species are not genetically isolated units and (d) that evolution is driven by the physical environment (ocean currents) rather than biological mechanisms (competition for survival) (Veron 2002). Furthermore, reticulate evolution does not deny the existence of Darwinian evolution which could become uppermost were genetic mixing to weaken sufficiently to create isolated gene pools. This would allow evolution to occur through biological selection. Conditions which promote reticulate evolution are at a maximum in the $\mathrm{CT}$ (sometimes referred to as an 'evolutionary cauldron') because of habitat diversity and the ever-changing complexity of ocean surface currents.

In summary, the diversity of the CT has no single explanation. Plate tectonics created the biogeographic template, one of complex island coastlines and extreme habitat heterogeneity. Patterns of dispersion, mediated by ocean currents, formed sequences of attenuation away from the equator leaving the $\mathrm{CT}$ with the region's highest biodiversity. Many environmental parameters, especially ocean currents and temperature, underpin this pattern. Evolutionary patterns, the genetic outcomes of environmental drivers, show why the $\mathrm{CT}$ is a centre of biodiversity.

\section{The future}

The future of the coral triangle is very much dependant on the future path of climate change impacts. The effects of bleaching are set to devastate shallow water coral communities during the first half of this century and the effects of ocean acidification will ensure that coral communities do not recover during the second half. This future outlook is bleak in a world where anthropogenic carbon dioxide emissions are not drastically reduced. However, there is hope in current political moves to address the issues. Comparing climate change scenarios,
Hoegh-Guldberg et al. (2009) concludes, "In one world, our attempts to stabilize the climate fails, as do our resolve to deal with the multitude of local threats to the health of coastal ecosystems in the Coral Triangle. In this world, planetary temperatures soar and the current rich coral reefs and mangroves ecosystems disappear, with huge impacts on food security, human survivorship and regional security. This is a world which we must avoid at all costs."

\section{Acknowledgements}

Gerry Allen (Western Australian Museum) and Peter Mous (Indonesian Ministry of Marine Affairs and Fisheries) contributed to the preparation of this manuscript. Tim Simmonds (AIMS) assisted with map preparations. The authors particularly thank The Nature Conservancy for supporting all aspects of the work.

\section{References}

Allen GR (2006) Coral reef fish diversity. In: Green A, Lokani P, Atu W, Ramohia P, Thomas P, Almany J (eds) Solomon Islands Marine Assessment. The Nature Conservancy Technical Report 1/06, pp 113-156

Allen GR (2007) Conservation hotspots of biodiversity and endemism for Indo-Pacific coral reef fishes. Aquatic Conservation: Marine and Freshwater Ecosystem 18: 541-556

Bartholomew JG, Clark WE, Grimshaw PH (1911) Atlas of zoogeography. Bartholomew, Edinburgh

Briggs JC (1984) Centers of biogeography. Biogeog Monogr 1. University of Leeds, Leeds

Briggs JC (2005) Coral reefs: conserving the evolutionary sources. Biol Conserv 126: 297-305

Bryant D, Burke L, McManus J, Spalding M (1998) Reefs at risk: a map-based indicator of threats to the world's coral reefs. World Resources Institute, Washington D.C.

Cairns SD (2007) Deep-water corals: an overview with special reference to diversity and distribution of deep-water scleractinian corals. Bull Mar Sci 81: 311-322

Carpenter KE and 32 co-authors (2008) One third of reefbuilding corals face elevated extinction risk from climate change and local impacts. Science 321: 560-564 
Clarke A (1992) Is there a latitudinal species diversity cline in the sea? Trends Ecol Evol 7: 286-287

Coudray J, Montaggioni L (1982) Coraux et recifs coralliens de la province Indo-Pacifique: repartitiongeographique et altitudinale en relation avec la tectonique globale. Bull Soc Geol Fr 24: 981-993

Dana JD (1853) On an isothermal oceanic chart illustrating the geographical distribution of marine animals. Am J Sci 16: 314-327

Darwin C (1859) The origin of species by means of natural selection, or the preservation of favoured races in the struggle for life. John Murray, London

Ekman S (1935) Tiergeographie des Meeres. Akademische Verlagsgesellschaft, Leipzig

Forbes E (1856) Map of the distribution of marine life. In: Johnston AK (ed) The physical atlas of natural phenomena, plate 31. Johnston W, Johnston AK, Edinburgh

George W (1964) Biologist philosopher: a study of the life and writings of Alfred Russel Wallace. Abelard-Schuman, London

George W (1981) Wallace and his line. In: Whitmore TC (ed) Wallace's Line and plate tectonics. Clarendon Press, Oxford

Gordon A, Fine R (1996) Pathways of water between the Pacific and Indian Oceans in the Indonesian seas. Nature 379: 146-149

Grave de S (2001) Biogeography of Indo-Pacific Pontoniinae shrimps (Crustacea: Decapoda): a PAE analysis. J Biogeogr 28: $1239-1253$

Groombridge B, Jenkins MD (2002) World atlas of biodiversity: Earth's living resources in the 21 st century. University of California Press, Berkeley, California

Halpern BS, Pyke CR, Fox HE, Haney JC, Schlaepfer MA, Zaradic P (2006) Gaps and mismatches between global conservation priorities and spending. Conserv Biol 20: 5664

Hoegh-Guldberg O and 20 co-authors (2009) The Coral Triangle and climate change: ecosystems, people and societies at risk. World Wildlife Fund, Brisbane

Hoeksema BW (2007) Delineation of the Indo-Malayan centre of maximum marine biodiversity: the Coral Triangle. In: Renema W (ed) Biogeography, time, and place: distributions, barriers, and islands. Springer, Netherlands, pp 117178

Hogarth PJ (1999) The Biology of Mangroves. Oxford University Press, Oxford, UK

Huxley TH (1868) On the classification and distribution of the
Alectoromorphae and heteromorphae. Proc Zool Soc Lond: 294-319

Jokiel P, Martinelli FJ (1992) The vortex model of coral reef biogeography. J Biogeogr 19: 449-458

Kelleher G (ed) (1999) Guidelines for Marine Protected Areas. IUCN World Commission on Protected Areas. Best Practice Protected Area Guidelines Series 3

Kleypas JA, Danabasoglu G Lough JM (2008) Potential role of the ocean thermostat in determining regional differences in coral reef bleaching events. Geophys Res Lett 35: L03613, doi:10.1029/2007GL032257

McCoy ED, Heck KL (1976) Biogeography of corals, seagrasses and mangroves: an alternative to the centre of origin concept. Syst Zool 25: 201-10

Meyer CP, Geller JB, Paulay G (2005) Fine scale endemism on coral reefs: archipelagic differentiation in turbinid gastropods. Evolution 59: 113-125

Ricklefs RE, Latham RE (1993) Global patterns of diversity in mangrove floras. In: Ricklefs RE, Schluter D (eds) Species diversity in ecological communities, historical and geographical perspectives. Chicago University Press, Chicago, pp 215-229

Rosen BR (1971) The distribution of reef coral genera in the Indian Ocean. In: Stoddart DR, Yonge CM (eds) Regional variation in Indian Ocean coral reefs. Symp Zool Soc Lond 28, pp 263-299

Siddall M, Rohling EJ, Almogi-Labin A, Hemleben C, Meischner D, Schmelzer I, Smeed DA (2003) Sea-level fluctuations during the last glacial cycle. Nature 423: 853-858

Spalding MD and 14 coauthors (2007) Marine ecoregions of the world: A bioregionalization of coastal and shelf areas. Bioscience 57: 573-583

Spalding MD, Taylor M, Ravilious C, Short F, Green E (2003) Global overview. The distribution and status of seagrasses. In: Green EP, Short FT (eds) World atlas of seagrasses. University of California Press, Berkeley, California, pp 5-26

Stehli FG, Wells JW (1971) Diversity and age patterns in hermatypic corals. Syst Zool 20: 115-126

Stevens GC (1989) The latitudinal gradient in geographical range: how so many species coexist in the tropics. Am. Nat. 133: 240-256

Turak E, DeVantier L (in press) Biodiversity and conservation priorities of reef-building corals in the Papuan Bird's Head Seascape. In: Katz LS, Firman A, Erdmann MV (eds) A Rapid Marine Biodiversity Assessment of Teluk Cendrawasih and the FakFak-Kaimana Coastline of the 
Papuan Bird's Head Seascape, Indonesia. RAP Bulletin of Biological Assessment. Conservation International, Washington, D.C.

Turak E, Souhoka J (2003) Coral diversity and the status of coral reefs in the Raja Ampat Islands. In: Donnelly R, Neville D, Mous P (eds) Report on a rapid ecological assessment of the Raja Ampat Islands, Papua, Eastern Indonesia, held October 30 - November 22, 2002. The Nature Conservancy Southeast Asia Center for Marine Protected Areas, Sanur, Bali Indonesia

Veron JEN, Stafford-Smith MG (2002) Coral ID. Australian Institute of Marine Science, Townsville. CD-ROM

Veron JEN (1993) A biogeographic database of hermatypic corals: species of the central Indo-Pacific, genera of the world. Aust Inst Mar Sci Monogr Ser 9

Veron JEN (1995) Corals in space and time: the biogeography and evolution of the Scleractinia. Cornell University Press, Ithaca, New York

Veron JEN (2000) Corals of the world (3 vols). Austalian Institute of Marine Science, Townsville

Veron JEN (2002) Reticulate evolution in corals. Proc 9th Int

\section{Coral Reef Symp: 43-48}

Wallace AR (1863) On the physical geography of the Malay Archipelago. J Roy Geogr Soc 33: 217-234

Wallace AR (1869) The Malay Archipelago (2 vols). Macmillan, London

Wallace AR (1910) The world of life. Chapman and Hall, London

Wells FE (2002) Centres of species richness and endemism of shallow-water marine molluscs in the tropical Indo-West Pacific. Proc 9th Int Coral Reef Symp: 941-945

Wells JW (1954) Recent corals of the Marshall Islands. US Geol Surv Prof Pap 260: 385-486

Wells JW (1955) A survey of the distribution of coral reef genera in the Great Barrier Reef region. Rep Great Barrier Reef Comm 6: 1-9

Received: 29 May 2009

Accepted: 24 September 2009

C Japanese Coral Reef Society 